\title{
International Scholarly Activity among Academic Librarians in the United States
}

\section{Anna Kozlowska and Jung Mi Scoulas}

\begin{abstract}
The extent of U.S. librarians' collaboration with international partners in the area of scholarly activity and research publications is still unexplored. Guided by Jane Knight's "At Home" framework for international research and scholarly activity, this study examines the extent of scholarly activity between librarians from the United States and international institutional and individual collaborators (that is, conference attendance, collaborations and staff exchanges, publications and collaborative authorship). A total of 193 U.S. academic librarians participated in an online survey. The results show that international research and scholarly activity is rare among U.S. librarians. Among the librarians who do participate in these activities, the results indicate that their participation in international conferences is associated with more internationalization activities.
\end{abstract}

\section{Introduction}

Library and information science (LIS) literature offers extensive evidence of library and librarians' contributions to internationalization activities on campuses. Common themes in the LIS literature regarding internationalization are the work of the library with international students, building international collections, promoting open access and resource sharing, and library staff exchange programs. ${ }^{1}$ However, the extent of librarian collaboration with international partners with regard to scholarly activity and research publications is still unexplored. The purpose of this study is to assess the extent to which U.S. librarians are involved in international research collaborations, what types of publications are produced as a result of these partnerships, and their engagement in additional types of international scholarly activities. Also, the authors will explore if there is any geographical disparity in terms of who is invited to form these collaborative relationships. Finally, this study aims to examine if there is a correlation between participation in international conferences and internationalization activities.

This research is the first study in the LIS field employing Knight's internationalization framework "At Home" with a particular focus on "research and scholarly activity." ${ }^{2}$ Identifying a baseline to encourage the growth of international activities in librarianship can create awareness and opportunities for expanded international scholarly activities between librarians. Thinking

Anna Kozlowska is Assistant Professor and Liaison Librarian at the University of Illinois at Chicago; email: akozlows@ uic.edu. Jung Mi Scoulas is Clinical Assistant Professor and Assessment Coordinator at the University of Illinois at Chicago; email: jscoul2@uic.edu. The authors gratefully appreciate their UIC colleagues who provided feedback and ongoing support for this manuscript: Rebecca Raszewski, Paula Dempsey, Glenda Insua, and Abigail Goben. Also thank you to Toby Reiner for his feedback on the first draft. (2020 Anna Kozlowska and Jung Mi Scoulas. 
transnationally about the issues concerning the library and information science profession such as rapid changes in technologies for information sharing, proliferation of disinformation and predatory publishers, internet security, and many other topics will require international cooperation to find and implement sustainable solutions. Finally, international collaboration in research projects can benefit the scholars from other regions in gaining exposure for their research, and for domestic scholars to truly explore original topics that are underrepresented in library literature.

\section{Literature Review}

LIS literature offers extensive evidence of the library and librarians' contribution to internationalization processes on campus, though in the higher education literature and in campus internationalization strategic plans, the role of the academic library as an agent or advocate of internationalization is often ignored or downplayed. ${ }^{3}$ Common themes in the library literature regarding internationalization are the work of the library with international students, building international collections, promoting open access and resource sharing, and library staff exchange programs. ${ }^{4}$ Despite some application of higher education international models, there has not been a study we are aware of measuring the extent of United States academic librarian collaboration with international partners in the area of scholarly activity and research publications. This literature review examines library and librarians' contributions to internationalization activities on campuses, as well as the role of the academic library and librarians in the area of international research and scholarly activity.

The need for international collaborations and global operations due to rapid development of technology as well as to the increase in student and scholars' mobility is well articulated in the LIS literature. ${ }^{5}$ According to Dewey, the global library must "address sweeping changes in technology transforming all aspects of creating, disseminating, and accessing scholarship in a multi-cultural world." 6 In addition, Smith examined a growing international collaborative effort in areas such as resource sharing, licensing, and archiving; however, she also identified a lack of literature pertaining to international collaboration in the area of training and development of academic library employees. In response to the demand for research in this area, she conducted a mixed methods study of library associations and their affiliates serving academic and research libraries worldwide. Her research explored collaborative initiatives, interest in sharing best practices internationally, and perceived rewards and barriers to engaging internationally. The focus group was arranged at the International Federation of Library Associations and Institutions (IFLA) General Conference and Assembly in Lyon. The study was conducted with participants of the largest and most important international library conference; therefore, it could be assumed that most participants have already well-established individual commitment to internationalization or come from more internationally focused institutions. ${ }^{7}$

The preeminent model for measuring the extent and quality of internationalization in institutions of higher education is the Center for Internationalization and Global Engagement (CIGE) Model for Comprehensive Internationalization created by the American Council on Education (ACE) presented in the report Mapping Internationalization on U.S. Campuses. Every five years, ACE surveys U.S. colleges and universities with the goal of assessing "the current state of internationalization at institutions, examin[ing] progress and trends over time, and identify[ing] priorities going forward." 8 Witt, Kutner and Cooper applied the CIGE Model to assess the contribution of academic libraries to internationalization processes. They adapted 
the survey from the ACE report and sent it to a national sample of U.S. library administrators to measure the extent to which international education and global learning are included in libraries' mission statements, strategic plans, and committee work. They concluded that very few academic libraries include internationalization in their mission statements; however, 44 percent of the responding institutions said that they articulate the commitment to internationalization in their strategic plans. In terms of activities most commonly supported by library faculty and staff, the highest ranked were liaising with foreign language and area/ international studies departments, providing instruction and orientations to international students, and building international and foreign language collections. Developing and monitoring international partnerships, access to foreign languages through international references, and supporting international branch campuses were ranked the lowest on the priority list. ${ }^{9}$ While this model provides an introduction to the service focus for academic libraries and internationalization on campuses, it is limited in that it does not address the potential or actual scholarly collaborations between academic librarians.

Click, Walker Wiley, and Houlihan conducted a systematic review of the literature in the LIS field with a focus on international students and academic libraries. Their study reviewed scholarly LIS literature published in English between 1990 and 2014 and found that articles published about international students and academic libraries steadily increased during that time period. Of particular interest was that only 4 percent of the 160 total articles reviewed $(n=6)$ were written with international collaborators. ${ }^{10}$ These findings call for further research about whether there is scholarship about the library's role in internationalization processes written in languages other than English.

One such study was conducted by Sánchez-Tarrago', Castellanos-Gallardo, and Santiago Bufrem. The scholars were from institutions in Spain, Ecuador, and Brazil, respectively. They used more general databases such as Scopus, Web of Science, and SciELO for their review of literature between 2005 and 2015. Scopus and Web of Science are abstract and citation databases of peer-reviewed literature, and SciELO is an online library that provides access to scholarly literature in Spanish and Portuguese from various countries of Latin America and Spain. Even though they expanded their research to include non-English language databases, their findings were similar to the Click, Walker Wiley, and Houlihan study. They identified publications by authors from 27 countries; the vast majority of scholarly works were produced in the United States, Canada, China, Australia, and the United Kingdom, whereas only two publications were from Latin America - both from Mexico. ${ }^{11}$

Important aspects of the research and scholarly activity internationalization framework are research exchange programs, international research partnerships in academic and other sectors, and integration of visiting researchers and scholars into academic activities on campus. ${ }^{12}$ There are many examples of such collaborations in the library literature. ${ }^{13}$ However, most of these articles describe particular experiences of librarians rather than systematic research and assessment on how these experiences contribute to the goal of internationalization. Kutner and Pond discussed an institutional affiliation agreement between the University of Vermont and Pontificia Universidad Católica del Perú (PUCP). The authors went to Peru to help PUCP librarians design and launch their thematic subject guides. ${ }^{14}$ Lee described the visit of the International Library and Cultural Exchange-Interest Group, an interest group of the Colorado Association of Libraries, to Nicaraguan libraries in San Juan del Sur. ${ }^{15}$ Heesen and Sellar reported on the partnership between Librarians Without Borders (LWB) and Librii in 
Ghana. ${ }^{16}$ There are many more examples in the literature of librarians from the United States, Europe, Canada, or Australia traveling to libraries in developing countries.

We conclude that there is a need for a comprehensive study about international research and scholarly activity among U.S. academic librarians. It is also important to explore if there is any geographical disparity in terms of who is invited to form these collaborative relationships between the librarians and libraries.

This study will seek to answer the following questions:

1. To what extent do U.S. academic librarians participate in international research and scholarly activities (that is, conference attendance, collaborations and staff exchanges, publications, and collaborative authorship)?

2. What are the reasons for not being involved in international research and scholarly activities?

3. Is there any geographical disparity between the Human Development Index (HDI) categories in terms of international library partnerships, research and staff exchanges, and research collaborations?

4. Is there a correlation between participation in international conferences and scholarly activities (like publications, collaborations, and staff exchanges)?

\section{Research Framework}

Jane Knight defines internationalization as the process of integrating an international, intercultural, or global dimension into the purpose, functions, or delivery of postsecondary education. ${ }^{17}$ She considers that there are two interdependent pillars of internationalization: "at home" and "abroad/cross-border." The "abroad/cross-border" aspect of internationalization pertains to mobility of people, programs, providers, projects/services and policy. On the other hand, the "at home" concept, according to Knight, was developed "to give greater prominence to campus-based strategies." ${ }^{18}$ The framework for internationalization "At Home" was chosen as a guiding framework for the survey design. This comprehensive framework includes six areas: 1) curriculum and programs, 2) teaching/learning process, 3) research and scholarly activity, 4) co-curricular activities, 5) extracurricular activities, and 6) liaison with local community-based cultural/ethnic groups. While there is substantial literature in the LIS field about working with international students and building foreign language collections, a significant gap remains in scholarship regarding international collaborations in the area of research and scholarly activity. In this area, Knight's framework includes such components as: area and theme centers, joint research projects, international conferences and seminars, published articles and papers, international research agreements, research exchange programs, international research partners in academic and other sectors, integration of visiting researchers and scholars into academic activities on campus.

\section{FIGURE 1}

\section{Framework for Internationalization "At Home" by Jane Knight (2012)}

Curriculum and Programs
- New programs with international theme infused with international, cultural, global, or comparative dimension into existing courses

- Foreign language study

- Area or regional studies

- Joint or double degrees 


\begin{tabular}{|c|c|}
\hline $\begin{array}{l}\text { Teaching/Learning } \\
\text { Process }\end{array}$ & $\begin{array}{l}\text { - Active involvement of international students, returned study-abroad students } \\
\text { and cultural diversity of classroom in teaching/learning process } \\
\text { - Virtual student mobility for joint courses and research projects } \\
\text { - Use of international scholars and teachers and local international/intercultural } \\
\text { experts } \\
\text { - Integration of international, intercultural case studies, role plays, problem- } \\
\text { solving scenarios, project-based learning, teams, learning communities, resource } \\
\text { materials } \\
\text { - Service learning } \\
\text { - Integration of global learning outcomes and assessment }\end{array}$ \\
\hline $\begin{array}{l}\text { Research and } \\
\text { Scholarly Activity }\end{array}$ & $\begin{array}{l}\text { - Area and theme centers } \\
\text { - Joint research projects } \\
\text { - International conferences and seminars } \\
\text { - Published articles and papers } \\
\text { - International research agreements } \\
\text { - Research exchange programs } \\
\text { - International research partners in academic and other sectors } \\
\text { - Integration of visiting researchers and scholars into academic activities on } \\
\text { campus }\end{array}$ \\
\hline Co-curricular Activities & $\begin{array}{l}\text { - International/global leadership development programs } \\
\text { - Interdisciplinary seminars and think tanks } \\
\text { - Distinguished speaker seminar }\end{array}$ \\
\hline $\begin{array}{l}\text { Extracurricular } \\
\text { Activities }\end{array}$ & $\begin{array}{l}\text { - Student clubs and associations } \\
\text { - International and intercultural campus events } \\
\text { - Language partners, friendship programs, student speaker programs } \\
\text { - Liaison with community-based cultural and ethnic groups } \\
\text { - Peer-support groups and programs }\end{array}$ \\
\hline $\begin{array}{l}\text { Liaison with Local } \\
\text { Community-based } \\
\text { Cultural/Ethnic } \\
\text { Groups }\end{array}$ & $\begin{array}{l}\text { - Involvement of students in local cultural and ethnic organization through } \\
\text { internships, volunteering, placements, and applied research } \\
\text { - Involvement of representatives from local cultural and ethnic groups in teaching/ } \\
\text { learning activities, research initiatives, and extracurricular events and projects }\end{array}$ \\
\hline
\end{tabular}

\section{Methods}

The authors employed a quantitative survey methodology to observe phenomena using quantified data about a particular group of people: in this case, librarians who work in US academic institutions. In addition, surveys allow for evaluation of the extent of research and scholarly activity. Other rationales behind this method include cost effectiveness and ability to reach a wide audience. However, one of the limitations of a cross-sectional survey design is the inability to ask follow-up questions. To address this problem, the researchers also included open-ended questions to give the participants the opportunity to elaborate on their responses and speak about topics that may not have been included in the original survey.

The survey questions consist of 27 multiple-choice, closed-ended, and open-ended questions covering various areas from Jane Knight's framework "At Home" for Research and Scholarly Activity (international collaborations, joint research projects, participation in international conferences and seminars, articles and papers published). Refer to appendix for 
survey questions. This study was approved by the Institutional Review Board (IRB) at the authors' institution (research protocol \# 2018-1611). The responses to the internationalization scholarly activity survey were collected between February 1 and March 13, 2019.

The participants were recruited through ALA Electronic Discussion Lists such as College Libraries Section (collib-1), ILI-L Discussion List (ili-1), ACRL Scholarly Communications (scholcomm), LIRT Members (lirt-1), ALA World (alaworld), and IFLA mailing list (ifla-1). A total of 221 librarians responded to this survey. Given that the current study targeted only librarians residing and working in the United States, 28 respondents who reside outside of US territory were excluded. As such, a total of 193 responses were selected for this study.

\section{Data Analysis}

Descriptive statistics (frequencies and percentage) were used to analyze quantitative questions using statistical software, Statistical Package for the Social Sciences (SPSS) version 25. To answer whether or not there is any geographical disparity in international library partnerships, research and staff exchanges, and research collaborations, the responses were organized by the Human Development Index (HDI), an indicator of the human development of a country created by the United Nations Development Program (UNDP). ${ }^{19}$ To test association between participation in international conferences and scholarly activities (publications, collaborations, and staff exchanges), a Pearson chi-square test was employed. The assumptions for a Person chi-square test were met because all the variables were measured at an ordinal or nominal level and they were independent groups. Variables include frequency of participation in international conference (once, 2-3 times, 4-6 times, and more than 7 times) at ordinal level and whether or not US librarians participate in the publications, collaboration, and staff exchange (yes and no) at nominal level. The chi-squared test is denoted as $\chi^{2}$.

\section{Results}

The current study aims to examine the extent of international research collaborations, what types of publications are produced as a result of these partnerships, and, beyond publishing, what other types of scholarly activity librarians are involved in. The results present participation in conferences, institutional international collaborations, and the extent of scholarly activity between US librarians and librarians from other parts of the world.

As shown in table 1, a vast majority of respondents $(66.09 \%)$ were affiliated with doctorategranting institutions, followed by master's colleges and universities (15.52\%). According to the Carnegie classification of US postsecondary institutions by degree level, doctoral universities account for 10 percent. ${ }^{20}$ In this study, 66 percent of respondents were from the doctorategranting institutions, indicating that the survey respondents from doctoral universities were well-represented. Most of the respondents (38.60\%) came from large institutions with more than 25,000 students. Most respondents were either at the beginning of their career (0-5 years, $31.40 \%)$ or had been in the field for longer than 21 years $(22.67 \%)$; however, mid-career librarians were also well represented. With regard to professional specialization, about half of respondents were instruction and department liaison librarians.

\section{Conferences}

Table 2 shows findings about librarians' participation in international conferences outside the United States: how frequently librarians attend international conferences, the locations of these 


\begin{tabular}{|c|c|c|}
\hline \multicolumn{3}{|l|}{$\begin{array}{c}\text { TABLE } 1 \\
\text { Academic Librarians' Demographic Information }\end{array}$} \\
\hline & $\%$ & Count \\
\hline \multicolumn{3}{|l|}{ Types of Institutions $(n=174)$} \\
\hline Doctorate-granting universities & $66.09 \%$ & 115 \\
\hline Master's colleges and universities & $15.52 \%$ & 27 \\
\hline Baccalaureate colleges & $7.47 \%$ & 13 \\
\hline Associate's colleges & $8.05 \%$ & 14 \\
\hline Special focus institutions & $1.72 \%$ & 3 \\
\hline Tribal colleges & $0.00 \%$ & 0 \\
\hline Other & $1.15 \%$ & 2 \\
\hline \multicolumn{3}{|l|}{ Size of Institutions $(n=171)$} \\
\hline Fewer than 5,000 & $17.54 \%$ & 30 \\
\hline $5,000-9,999$ & $16.37 \%$ & 28 \\
\hline $10,000-14,999$ & $12.28 \%$ & 21 \\
\hline $15,000-19,999$ & $7.02 \%$ & 12 \\
\hline $20,000-24,999$ & $8.19 \%$ & 14 \\
\hline More than 25,000 & $38.60 \%$ & 66 \\
\hline \multicolumn{3}{|l|}{ Years $(n=172)$} \\
\hline $0-5$ & $31.40 \%$ & 54 \\
\hline $6-10$ & $20.35 \%$ & 35 \\
\hline $11-15$ & $12.79 \%$ & 22 \\
\hline $16-20$ & $12.79 \%$ & 22 \\
\hline Longer than 21 & $22.67 \%$ & 39 \\
\hline \multicolumn{3}{|l|}{ Specialization Area within Librarianship ( $n=324)$} \\
\hline Director of the library & $5.11 \%$ & 18 \\
\hline Instruction librarian & $25.24 \%$ & 79 \\
\hline Electronic resources librarian & $3.19 \%$ & 10 \\
\hline Technical services (cataloger, electronic resources, acquisition) & $2.88 \%$ & 9 \\
\hline Liaison to international students & $1.60 \%$ & 6 \\
\hline Liaison to study-abroad programs & $1.92 \%$ & 7 \\
\hline Collection development & $8.63 \%$ & 27 \\
\hline Department liaison (write your subjects) & $23.00 \%$ & 73 \\
\hline Outreach/engagement librarian & $6.71 \%$ & 21 \\
\hline Special collections & $3.83 \%$ & 12 \\
\hline Archives & $1.92 \%$ & 6 \\
\hline Other & $15.97 \%$ & 50 \\
\hline Scholarly communication & $1.85 \%$ & 6 \\
\hline
\end{tabular}


conferences, and librarians' roles at these events. About 47 percent of respondents indicated that they participated in an international conference outside the United States. More than 60 percent of librarians had been to international conferences 1 to 3 times in their career. About 16 percent of the respondents reported that they attended international conferences more than 7 times. In terms of roles played at these conferences, most respondents attended as participants $(39.88 \%)$ and presenters $(34.52 \%)$. Among the 53 percent who had never participated in international conferences outside the United States, the most prevailing reasons were "too expensive" (45.28\%), "my library doesn't finance international travel" (22.64\%), and "I have never thought about it" (12.58\%).

\begin{tabular}{|c|c|c|}
\hline \multicolumn{3}{|c|}{$\begin{array}{c}\text { TABLE } 2 \\
\text { Descriptive Statistics for Conference (Frequencies, Roles, and Locations) }\end{array}$} \\
\hline & $\%$ & Count \\
\hline \multicolumn{3}{|l|}{ Conference $(n=185)$} \\
\hline \begin{tabular}{l|l} 
Yes \\
\end{tabular} & $47.03 \%$ & 87 \\
\hline No & $52.97 \%$ & 98 \\
\hline \multicolumn{3}{|l|}{ Conference: Frequencies $(n=87)$} \\
\hline \begin{tabular}{l|l} 
Once \\
\end{tabular} & $31.03 \%$ & 27 \\
\hline $2-3$ times & $33.33 \%$ & 29 \\
\hline 4-6 times & $19.54 \%$ & 17 \\
\hline More than 7 times & $16.09 \%$ & 14 \\
\hline \multicolumn{3}{|l|}{ Conference: Roles $(n=168)$} \\
\hline \begin{tabular}{l|l} 
& Participant \\
\end{tabular} & $39.88 \%$ & 67 \\
\hline Presenter & $34.52 \%$ & 58 \\
\hline Poster presentation & $10.12 \%$ & 17 \\
\hline Moderator & $6.55 \%$ & 11 \\
\hline Organizer & $5.36 \%$ & 9 \\
\hline Other (Please specify) & $3.57 \%$ & 6 \\
\hline \multicolumn{3}{|c|}{ Conference: Reasons for Not Attending Conferences $(n=159)$} \\
\hline \begin{tabular}{l|l} 
Not interested \\
\end{tabular} & $2.52 \%$ & 4 \\
\hline My library doesn't finance international travel & $22.64 \%$ & 36 \\
\hline Security concerns & $1.89 \%$ & 3 \\
\hline Difficulty with obtaining visa & $0.00 \%$ & 0 \\
\hline Too expensive & $45.28 \%$ & 72 \\
\hline I have never thought about it & $12.58 \%$ & 20 \\
\hline Language barrier & $6.29 \%$ & 10 \\
\hline Other & $8.81 \%$ & 14 \\
\hline
\end{tabular}

Among the US librarians who participated in international conferences, the majority of the respondents traveled to either Europe (32.37\%) or Canada (30.64\%) (see figure 2).

\section{Collaboration and Staff Exchanges}

Fewer than 20 percent of respondents indicated that their libraries had research partnerships 


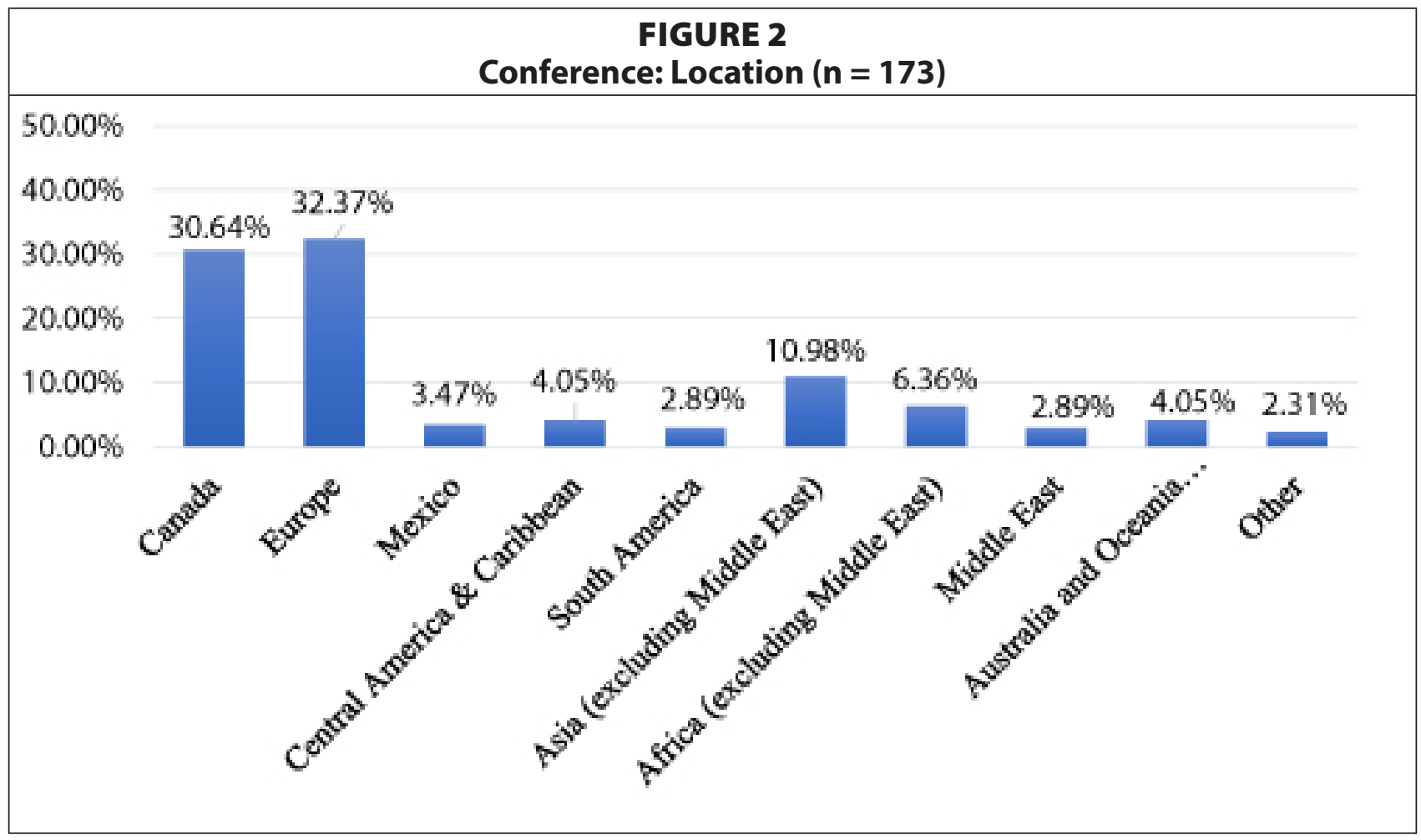

with other international academic libraries. Among them, the most commonly mentioned countries included China, Poland, and Germany, followed by Mexico and Japan. In terms of international research agreements, only 10 percent of respondents replied that their libraries had research agreements. When asked about the details of these agreements, some respondents mentioned special agreements related to a grant project (such as Fulbright placement), academic exchange programs between institutions (for instance, $\mathrm{PhD}$ programs) or sharing resources between institutions (like library collection and services). Regarding participation in international research or staff exchanges, only 14 percent of the respondents indicated that they participated in such programs.

\section{Conferences, Collaboration, and Publications by Type of Institutions}

Librarians' internationalization activities were further organized by the types of institutions. As shown in figure 3, most respondents, regardless of the type of institution $(72 \%-100 \%)$, reported that they never participated in international scholarly activities (participating in the international conferences, having international research agreements with foreign institutions, and staff exchange programs). However, only respondents from doctorate-granting institutions were involved in all three activities. Respondents from master's colleges and universities tended to have research agreements with foreign institutions and to participate in research or staff exchanges, whereas those from baccalaureate colleges and associate's colleges were likely to have partnerships with academic libraries and participate in research or staff exchanges.

\section{Publications and Collaborative Authorship}

The main focus of this study is to measure the extent and quality of publishing activities between the academic librarians from the United States and other countries. Table 3 shows 


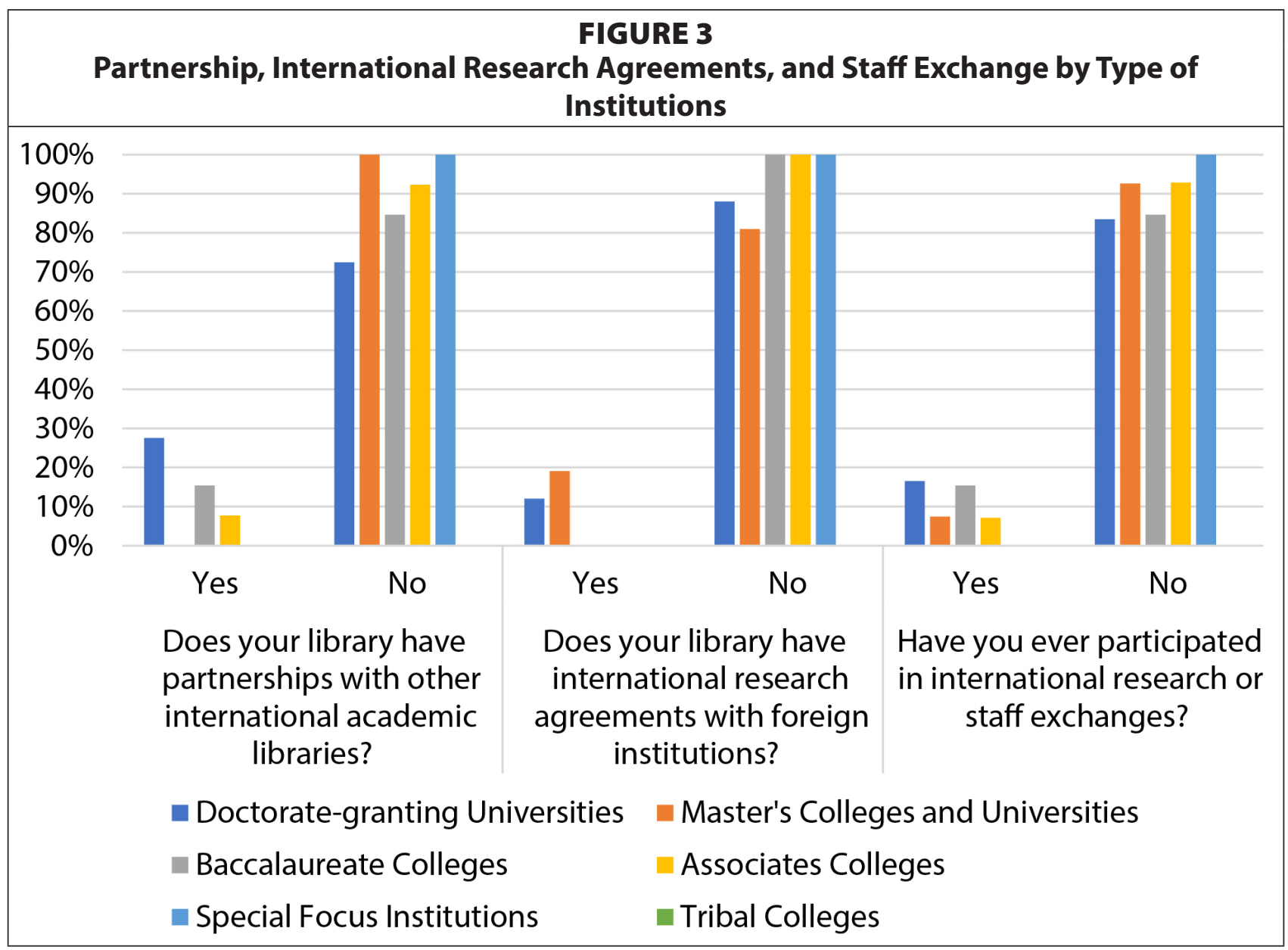

the descriptive statistics for publication activities in detail. The majority of the respondents $(83.15 \%)$ reported that they had never collaborated with an international partner, whereas only 17 percent of respondents answered that they published their works with international collaborators.

For those respondents who did not collaborate with other librarians on publishing articles, the reasons they gave include "I don't know where and how" (39.06\%), "logistical constraints" $(10.94 \%)$, and "lack of support from the library" (7.81\%). About 20 percent of respondents chose option "Other" and described constraints including lack of requirements or incentives to perform research or publish, high workload, a primary focus on domestic issues, or an opportunity having not presented itself yet.

Among the 17 percent of respondents who published with international collaborators, about 42 percent of respondents published more than seven times in their career. The types of publications indicated were research articles $(32.76 \%)$, followed by conference proceedings $(20.69 \%)$ and book chapters $(20.69 \%)$. In addition, about 20 percent of respondents indicated that they collaborated with international partners on other nonpublishing projects. The most commonly mentioned were conference presentations and panels, organization of conferences and workshops, committee work, exchange of curriculum and instruction ideas, and collaboration in areas of scholarly communications.

Librarians were further asked about how they developed collaborations. Of those who responded that they collaborated, they said that they met at a conference $(30.56 \%)$, followed by 


\begin{tabular}{|c|c|c|}
\hline \multicolumn{3}{|c|}{$\begin{array}{c}\text { TABLE } 3 \\
\text { Descriptive Statistics for Publication Activities and Collaborative Authorship }\end{array}$} \\
\hline & $\%$ & Count \\
\hline \multicolumn{3}{|l|}{ Publication Experience with International Collaborator $(n=184)$} \\
\hline Yes & $16.85 \%$ & 31 \\
\hline No & $83.15 \%$ & 153 \\
\hline \multicolumn{3}{|c|}{ Reasons for Not Being Involved in Publications with International Collaborator $(n=256)$} \\
\hline I don't know where and how to look for international collaborators & $39.06 \%$ & 100 \\
\hline Other & $18.36 \%$ & 47 \\
\hline Logistical constraints (time difference, distance, and so on) & $10.94 \%$ & 28 \\
\hline Lack of support from the library & $7.81 \%$ & 20 \\
\hline Difficulties with obtaining IRB approval or other institutional constraints & $5.86 \%$ & 15 \\
\hline I prefer to work alone & $4.30 \%$ & 11 \\
\hline Not interested & $3.91 \%$ & 10 \\
\hline Language barrier & $3.52 \%$ & 9 \\
\hline Cultural barriers & $1.56 \%$ & 4 \\
\hline Different writing conventions & $1.17 \%$ & 3 \\
\hline I believe domestic collaborations have more to offer & $1.17 \%$ & 3 \\
\hline Different work ethic & $0.78 \%$ & 2 \\
\hline Different understanding of plagiarism & $0.78 \%$ & 2 \\
\hline Need for extensive editing & $0.78 \%$ & 2 \\
\hline \multicolumn{3}{|l|}{ Frequency of Publication $(n=31)$} \\
\hline Once & $32.26 \%$ & 10 \\
\hline $2-3$ times & $22.58 \%$ & 7 \\
\hline $4-6$ times & $3.23 \%$ & 1 \\
\hline More than 7 times & $41.94 \%$ & 13 \\
\hline \multicolumn{3}{|l|}{ Collaboration: Type $(n=58)$} \\
\hline Research article & $32.76 \%$ & 19 \\
\hline Conference proceedings & $20.69 \%$ & 12 \\
\hline Book chapter & $20.69 \%$ & 12 \\
\hline Case study & $8.62 \%$ & 5 \\
\hline Book & $6.90 \%$ & 4 \\
\hline Other & $5.17 \%$ & 3 \\
\hline Newsletter & $3.45 \%$ & 2 \\
\hline Literature review & $1.72 \%$ & 1 \\
\hline
\end{tabular}

connecting through a colleague $(13.89 \%)$, a listserv $(11.11 \%)$, and social media $(2.78 \%)$. However, the majority of respondents selected option "Other" (41.67\%) and reported that they met as students during their LIS program or ended up collaborating through other projects such as committee work. When asked about the medium of communication used with international collaborators, top five were: email (35.29\%), Skype (15.29\%), phone calls (12.94\%), Zoom (9.4\%), and WhatsApp (5.88\%). 


\section{Countries by Human Development Index (HDI)}

The researchers further categorized countries enlisted in questions about international library partnerships, research and staff exchanges, and research collaborators according to the $\mathrm{Hu}$ man Development Index (HDI). HDI is an indicator of the human development of a country created by the United Nations Development Program (UNDP). The researchers used HDI as a marker of a general quality of life in countries where these international scholarly activities take place to analyze if there are any geographical disparities. The HDI is the geometric mean of normalized indices for each of the three dimensions: long and healthy life (life expectancy at birth), knowledge (mean of years of schooling for adults aged 25 years and more and expected years of schooling for children of school-entering age), and a decent standard of living (gross national income per capita). ${ }^{21}$ The reason behind using this indicator was to explore if there is any geographical disparity between the Human Development Index (HDI) categories in terms of international library partnerships, research and staff exchanges, and research collaborations. In other words, the authors were seeking to identify which regions are included and which excluded from this community of international scholarship in the library field. Internationalization activities (co-authored publications, library partnerships and staff exchanges) were further grouped by HDI (see figure 4). Regarding international library partnerships, 59 percent of them were with the libraries in the "very high" HDI countries, 29 percent in "high," and only 5 percent in "medium" and 7 percent in "low." When asked about which countries the librarians had been to for research and staff exchanges, 49 percent of them went to "very high" HDI countries, 26 percent in "high," 13 percent in "medium," and 13 percent in "low." Finally, in terms of countries of origin where the collaborators came from, 70 percent of them were from "very high" HDI countries, 12 percent from "high," 13 percent from "medium," and only 5 percent from "low." In the majority of countries listed in this question, English was the primary language, with the United Kingdom, Canada, and Australia leading the list.

\section{FIGURE 4}

Percentage of Countries by Human Development Index (HDI)

Have you ever published an article or paper with an international collaborator?

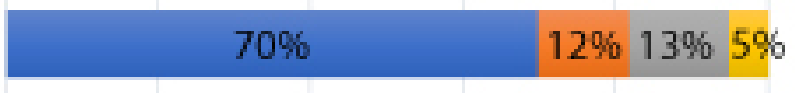

Have you ever participated in international research or staff exchanges?

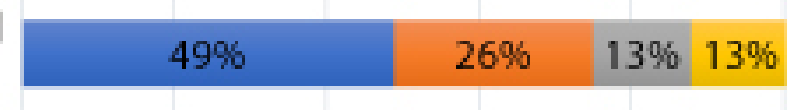

$26 \%$

$13 \% 13 \%$

Does your library have partnerships with other international academic libraries?

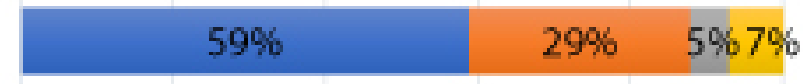

$0 \% \quad 20 \% \quad 40 \% \quad 60 \% \quad 80 \% \quad 100 \%$

Very High $=$ High $=$ Medium $=$ Low 


\section{Correlations between Internationalization Activities}

The authors further examined the relationships between the frequency of participation in international conferences and scholarly activities (publications, collaborations, and staff exchanges) by using Pearson's chi-square test. The results indicate that there is a statistically significant association between the frequency of participation in international conferences and all of the internationalization activities (publications with an international collaborator, $\chi^{2}(3)=34.82$, $p=.000$; collaboration on another project, $\chi^{2}(3)=12.09, p=.007$; participation in international research or staff exchange, $\left.\chi^{2}(3)=17.95, p=.000\right)$. The graph further shows a positive association (see figure 5). These findings suggest that the more librarians attend the international conferences, the more likely they are to have published with an international collaborator, collaborated on another project, or participated in international research or staff exchange.

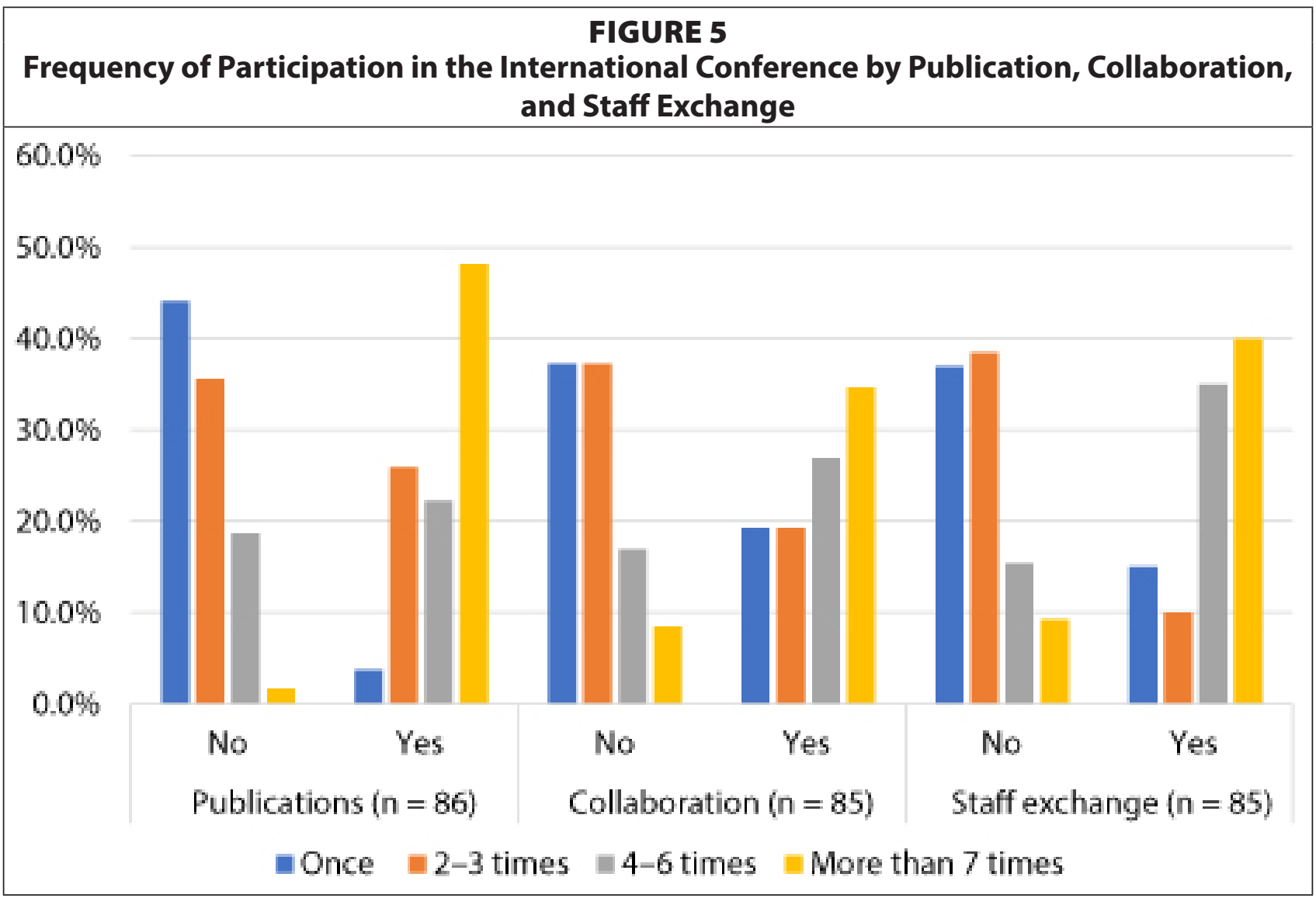

\section{Discussion and Future Directions}

When one looks across the data by institution type, it can be easily observed that only respondents from doctorate-granting institutions were involved in all three types of international activity (see figure 3). One of the potential reasons could be a lack of financial support for internationalization activities at other types of libraries. The current study confirmed that financial considerations (examples: "too expensive" and "my library doesn't finance international travel") were the primary reasons for not participating in international conferences (67.92\%). This is further supported by Witt, Kutner, and Cooper's study, showing that only 16 percent of libraries reported that they receive internal funding to support internationalization activities. In addition, the librarians at doctorate-granting institutions indicated their admin- 
istrations are more likely "to sponsor workshops on international trends in librarianship and support international travel to meetings and professional activities" 22 than in master's and bachelor's institutions.

Another possible explanation may be the absence of a research requirement in librarians' job descriptions - this arose as a reason why some librarians have never collaborated with international partners. These findings provide a potential justification for the lack of international research and scholarly activity among academic librarians, especially in nondoctoral institutions. However, a further analysis to determine the causes is necessary.

According to the 2017 Mapping Internationalization on U.S. Campuses report, doctorategranting universities continue to lead in internationalization initiatives; however, other types of institutions such as associate's and special-focus institutions have seen considerable advances, especially in activities pertaining to curriculum. Also, based on the last few years' lists of recipients of Simon Award for Campus Internationalization conferred by NAFSA: Association of International Educators, it is apparent that other institutions from Carnegie Classification are strongly represented. Therefore, these advances may encourage libraries from nondoctoral institutions to think about how to align their goals with internationalization focuses and progress at their institutions.

The findings from the study also provide insight into regional disparities between the HDI categories in terms of international library partnerships, research and staff exchanges, and research collaborations. As discussed in previous section, more than 70 percent of librarian collaborations were with authors from "very high" HDI countries and only 5 percent with "low" development index countries. Similarly, 59 percent of international partnerships were with libraries in "very high" HDI countries, while only 7 percent with "low" HDI. Slightly more promising are results about international staff exchanges where the disparity was 49 percent "very high" HDI and 13 percent "low" HDI.

Another key finding is that there is a strong relationship between participation in international conferences and academic publishing with international collaborators. The study results confirm that librarians who frequently go to international conferences have more partnerships, from academic publishing and conference presentations to cooperating on international policies and committee work. One of the most effective ways to find international collaborators and learn about library trends worldwide is through participation in international conferences. ${ }^{23}$ Among the librarians who did participate in international conferences, most went to either Europe (32.37\%) or Canada (30.64\%). Undoubtedly, there are many opportunities for librarians to attend international conferences; however, if we take a closer look at where these major events take place, we notice that certain regions are excluded from participation in this international community. For example, for the last 10 years, IFLA WLIC congresses were hosted in cities and countries such as: Quebec, Canada (2008); Milan, Italy (2009); Gothenburg, Sweden (2010); San Juan, Puerto Rico (2011); Helsinki, Finland (2012); Singapore, Singapore (2013); Lyon, France (2014); Cape Town, South Africa (2015); Columbus, United States (2016); Wroclaw, Poland (2017); Kuala Lumpur, Malaysia (2018). The 2019 IFLA conference took place in Athens, Greece. Therefore, as the list shows, most of these conferences take place in developed countries with often stringent visa requirements. It is essential for organizations such as IFLA, who is "the global voice of the library and information profession," ${ }^{24}$ to take a deliberate approach in equalizing opportunities for attendance for librarians from developing countries. While organization 
of such a big event in some regions could be impossible due to security reasons or lack of infrastructure, there is a necessity to create alternative forms of networking opportunities. IFLA organizes virtual conferences and webinars; however, even the cost of membership can create a serious obstacle to participation. There is a differentiated fee structure based on the region for institutional members, but not for individual affiliates. There are also very few grants available to participants from developing countries to participate in annual IFLA WLIC conferences. In addition, most of the grants cover the conference registration fee and a small stipend significantly below the costs of airfare, lodging, and visa. ${ }^{25}$

Due to the realities of funding, time limitations, visa restrictions, and other considerations, it is also important that librarians are able to identify ways to participate internationally and connect with colleagues in ways that do not require extensive infrastructure and funds. The most commonly chosen response to the question of why librarians have never collaborated with international partners from this study was "I don't know where and how" (39.06\%). Therefore, it may indicate that US librarians are interested in such collaborations but do not know the venue that could connect them with international collaborators. There are many successful networking websites such as ALA Connect or Mixxer (a language exchange site hosted by Dickinson College) that can serve as models for building a networking site for librarians from all over the world.

As we have seen in the literature review, some of the described examples reveal a troubling asymmetry of power in collaborations between the sending and the host country. Knight mentioned homogenization rather than diversification of world cultures as one of the unintended negative consequences of internationalization. ${ }^{26}$ Witt, Pino-Yancovic, and Neal also commented "sightseeing" and "volunteerism" in study/work abroad experiences as a tool for deepening inequality. ${ }^{27}$ Breen called this phenomenon "academic tourism." ${ }^{28}$ Because experiential literature represents a large share of articles produced in the library field regarding international staff exchanges, a closer look at the content and meaning of these collaborations is recommended.

International collaborations on research publications present the best opportunity to lessen the divide between the global South and global North. According to Collyer, "Citation analysis adds quantitative evidence of the unequal bifurcation of world knowledge production, showing scholars in the global North to be self-citing and inward-looking, while in the periphery, citations are primarily directed toward the publications of the core countries." ${ }^{29}$ Many other studies have discussed this dominance in knowledge production; ${ }^{30}$ unfortunately, librarianship research presents a similar pattern. Therefore, co-authorship with international scholars, especially those from "high," "medium," and "low" HDI countries can benefit scholars in gaining exposure for their research and domestic scholars who wish to truly explore original topics that are underrepresented in library literature. Moreover, co-publication is an example of a relationship of equals rather than promotion of the division between "us" and "them."

\section{Conclusion}

The goal of this research was to explore the extent of scholarly activity between librarians from the United States and international institutional and individual collaborators. Based on the collected data and extensive literature review, it can be concluded that there is not much activity in the area of international research and scholarly activity among US librarians. One limitation of the study was that the results were self-reported; an updated comprehensive review of the existing co-authored literature would be recommended. 
Furthermore, this research uncovered what types of publications are produced as a result of existing international partnerships and, beyond publishing, what other types of scholarly activity librarians are involved in with international peers. Finally, it explored the extent of international partnership agreements between libraries, attendance in international conferences outside of the United States, and the amount of geographical disparity in terms of who has access and who is excluded from scholarly communication. There are many more questions requiring further study and analysis, and this study is just the beginning of a broader conversation about how to promote quality internationalization in US academic libraries regarding international research and scholarly activity. 


\section{APPENDIX. Survey Questions}

\section{Internationalization Activity Survey}

Thank you for participating in this study of the extent and quality of efforts by academic librarians to internationalize research and scholarly activity. Your participation will help us determine how common international research collaborations are, what types of publications are produced as a result of these partnerships, and, beyond publishing, what other types of scholarly activity librarians are involved in. This is important as a baseline to encourage the growth of international activities in librarianship.

Q1 Do you reside and work in an academic library in the United States?

$\square$ Yes

- No

Q2 Have you ever published in the Library and/or Information Science (LIS) field?

口 Yes

$\square$ No

Q3 During your time as a professional librarian, have you ever been to an international conference or seminar outside the United States?

口 Yes

$\square$ No

Q4 Why have you never attended an international conference or seminar? Please select all that apply.

$\square$ Not interested

My library doesn't finance international travel

Security concerns

$\square$ Difficulty with obtaining visa

$\square$ Too expensive

I have never thought about it

口 Language barrier

$\square$ Other

Q5 How many times have you attended international conferences and/or seminars?

口 Once

2-3 times

4-6 times

- More than 7 times

Q6 Where did this international conference or seminar take place? Please select all that apply:

$\square$ Canada

$\square$ Europe

$\square$ Mexico

Central America \& Caribbean

$\square$ South America

- Asia (excluding Middle East)

․ Africa (excluding Middle East)

$\square$ Middle East

$\square$ Australia and Oceania (including New Zealand) 
$\square$ Other

Q7 What was your role at those conferences and/or seminars? Please select all that apply:

$\square$ Participant

$\square$ Presenter

$\square$ Poster presentation

$\square$ Moderator

$\square$ Organizer

$\square \quad$ Other (Please specify)

Q8 Does your library have partnerships with other international academic libraries?

$\square$ Yes

$\square \quad \mathrm{No}$

$\square \quad$ I don't know

Q9 Please list the countries where the partnering library/ies is/are located.

Q10 Does your library have international research agreements with foreign institutions?

$\square$ Yes

$\square \quad$ No

I I don't know

Q11 Please briefly describe the content of the agreements.

Q12 Have you ever published an article or paper with an international collaborator?

$\square$ Yes

$\square \quad$ No

Q13 Why have you never cooperated on any project with an international collaborator? Select all that apply.

$\square \quad$ Not interested

$\square \quad$ I prefer to work alone

$\square \quad$ Language barrier

$\square$ Different work ethic

$\square \quad$ I don't know where and how to look for international collaborators

$\square$ Different understanding of plagiarism

$\square$ Logistical constraints (time difference, distance, other constraints)

$\square \quad$ Cultural barriers

$\square$ Difficulties with obtaining IRB approval or other institutional constraints

$\square$ Different writing conventions

$\square \quad$ I believe domestic collaborations have more to offer

$\square$ Lack of support from the library

$\square \quad$ Need for extensive editing

$\square$ Other

Q14 What type of publication? Please select all that apply.

$\square \quad$ Research article

$\square$ Literature review

$\square$ Newsletter

$\square$ Case study 
$\square$ Conference proceedings

$\square$ Book chapter

$\square$ Book

$\square$ Other

Q15 How many times have you published?

$\square$ Once

$\square \quad 2-3$ times

ㄴ 4-6 times

$\square \quad$ More than 7 times

Q16 Please list all the countries your collaborators are from.

Q17 Have you ever collaborated with international scholars/librarians from institutions in other countries on any other project (such as posters, exhibits, or digital works)?

$\square$ Yes

$\square \quad$ No

Q18 Please describe the types of collaboration.

Q19 How did you end up collaborating?

$\square$ Met at a conference

$\square$ Connected through a listserv

$\square$ Connected through social media. Please write the name

$\square$ Connected through a colleague

$\square$ Other

Q20 Through which medium did you end up collaborating? Please select all that apply.

$\square$ Skype

$\square$ WhatsApp

$\square$ WeChat

$\square$ Facebook

$\square$ Twitter

$\square$ SnapChat

$\square \quad$ Phone calls

$\square \quad$ Email

$\square$ Other

Q21 Have you ever participated in international research or staff exchanges?

$\square$ Yes

$\square \quad$ No

Q22 Please list all the countries that apply.

Q23 Please describe any additional information about internationalization activities at your library that have not been addressed. If you have any further questions or comments about 
this study, please contact the Principal Investigator, Anna Kozlowska at akozlows@uic.edu.

Q24 At what type of institution do you work?

$\square$ Doctorate-granting universities

$\square \quad$ Master's colleges and universities

$\square$ Baccalaureate colleges

$\square \quad$ Associates' colleges

$\square$ Special-focus institutions

$\square \quad$ Tribal colleges

$\square \quad$ Other

Q25 How many students are at your institution?

$\square$ Fewer than 5,000

口 5,000-9,999

10,000-14,999

$\square \quad 15,000-19,999$

20,000-24,999

$\square \quad$ More than 25,000

Q26 What is your specialization area within librarianship? Please select all that apply.

$\square \quad$ Director of the library

$\square \quad$ Instruction librarian

$\square \quad$ Electronic rresources librarian

$\square$ Technical services (cataloger, electronic resources, acquisition)

$\square \quad$ Liaison to international students

$\square \quad$ Liaison to study-abroad programs

$\square$ Collection development

$\square$ Department liaison (write your subjects)

$\square$ Outreach/engagement librarian

$\square \quad$ Special collections

$\square$ Archives

$\square$ Other

Q27 For how many years have you been a librarian?

$\square \quad 0-5$

$\square \quad 6-10$

11-15

ㅁ 16-20

$\square \quad$ Longer than 21

\section{Notes}

1. Steven W. Witt, Laurie Kutner, and Liz Cooper, "Mapping Academic Library Contributions to Campus Internationalization," College and Research Libraries 76, no. 5 (2015): 587-608; Amanda B. Click, Claire Walker Wiley, and Meggan Houlihan, "The Internationalization of the Academic Library: A Systematic Review of 25 Years of Literature on International Students," College and Research Libraries 78, no. 3 (2017): 328-58; Nancy Sánchez-Tarragó, Inalvis Castellanos-Gallardo, and Leilah Santiago Bufrem, “Contribuciones de la Biblioteca 
Universitaria a la Internacionalización del Campus: Análisis Sistemático de la Literatura," Perspectivas em Ciencia da Informacao 22, no. 3 (2017): 186-209.

2. Jane Knight, "Concepts, Rationales, and Interpretive Frameworks in the Internationalization of Higher Education," in The SAGE Handbook of International Higher Education, eds. Darla K. Deardorff, Hans J. de Wit, John D. Heyl, and Tony Adams (Thousand Oaks, CA: SAGE Publications Ltd., 2012).

3. Karen Bordonaro, Internationalization and the North American University Library (Plymouth, UK: Scarecrow Press, 2013); Witt, Kutner, and Cooper, "Mapping Academic Library Contributions to Campus Internationalization."

4. Witt, Kutner, and Cooper, "Mapping Academic Library Contributions to Campus Internationalization"; Click, Walker Wiley, and Houlihan, "The Internationalization of the Academic Library"; Sánchez-Tarragó, Castellanos-Gallardo, and Santiago Bufrem, "Contribuciones de la Biblioteca Universitaria a la Internacionalización del Campus"; Bordonaro, Internationalization and the North American University Library.

5. Bonnie J. Smith, "Broadening Our Scope: International Collaboration for Retooling the Academic Library," Journal of Library Administration 56, no. 4 (2016): 395-415; Barbara Dewey, Transforming Research Libraries for the Global Knowledge Society (Oxford, UK: Chandos Publishing, 2010).

6. Dewey, Transforming Research Libraries for the Global Knowledge Society, 4.

7. Smith, "Broadening Our Scope."

8. American Council on Education (ACE), Mapping Internationalization on U.S. Campuses 2017 Edition (Washington, DC: American Council on Education, 2017): 4.

9. Witt, Kutner, and Cooper, "Mapping Academic Library Contributions to Campus Internationalization."

10. Click, Walker Wiley and Houlihan, "The Internationalization of the Academic Library."

11. Sánchez-Tarragó, Castellanos-Gallardo, and Santiago Bufrem, "Contribuciones de la Biblioteca Universitaria a la Internacionalización del Campus."

12. Knight, "Concepts, Rationales, and Interpretive Frameworks in the Internationalization of Higher Education."

13. Laurie Kutner and Fred Pond, "Deepening Ties between the Pontifical Catholic University of Peru and the University of Vermont," International Leads, 30 no. 4 (2016): 4-5; Janet Lee, "Colorado Librarians Explore Nicaraguan Libraries," International Leads 29, no. 4 (2015): 4; Erika Heesen and Melanie Sellar, "International Collaborations: Librarians without Borders and Librii in Ghana," Feliciter 59, no. 6 (2013): 35-37.

14. Kutner and Pond, "Deepening Ties between the Pontifical Catholic University of Peru and the University of Vermont."

15. Lee, "Colorado Librarians Explore Nicaraguan Libraries."

16. Heesen and Sellar, "International Collaborations."

17. Knight, "Concepts, Rationales, and Interpretive Frameworks in the Internationalization of Higher Education": definition first introduced in Jane Knight, "Internationalization Remodeled: Definitions, Rationales, and Approaches," Journal for Studies in International Education 8, no. 1 (2004): 5-31.

18. Knight, "Concepts, Rationales, and Interpretive Frameworks in the Internationalization of Higher Education."

19. United Nations Development Programme, "Human Development Index (HDI)," http://hdr.undp.org/en/ content/human-development-index-hdi.

20. Carnegie Classification of Institutions of Higher Education, "News \& Announcements

2018 Classification Update," http://carnegieclassifications.iu.edu/.

21. UNDP, “Human Development Index (HDI),” http://hdr.undp.org/en/content/human-development-indexhdi.

22. Witt, Kutner, and Cooper, "Mapping Academic Library Contributions to Campus Internationalization," 601.

23. Ismail Abdullahi and Leif Kajberg, "A Study of International Issues in Library and Information Science Education: Survey of LIS Schools in Europe, the USA and Canada," New Library World 105, no. 1204/1205 (2004): 345-56; Ismail Abdullahi, Leif Kajberg, and Sirje Virkus, "Internationalization of LIS Education in Europe and North America," New Library World 108, no.1/2 (2007): 7-24.

24. IFLA, "About IFLA," https://www.ifla.org/about.

25. IFLA, “IFLA WLIC 2020,” https://2020.ifla.org/apply-for-grants/; “IFLA WLIC 2019,” https://2019.ifla.org/ congress-information/conference-participation-grants/.

26. Knight, "Concepts, Rationales, and Interpretive Frameworks in the Internationalization of Higher Education."

27. Allison Witt, Mauricio Pino-Yancovic, and Brandi Neal, "Critical Learning and Teaching" (unpublished draft). 
28. Marcus Breen, "Privileged Migration: American Undergraduates, Study Abroad, Academic Tourism." Critical Arts 26, no. 1 (2012): 82-102.

29. Fran M. Collyer, "Global Patterns in the Publishing of Academic Knowledge: Global North, Global South," Current Sociology 66, no. 1 (2018): 66.

30. Raewyn Connell, Southern Theory (Cambridge, UK: Polity, 2007); Pranee Liamputtong, "Doing Research in a Cross-Cultural Context: Methodological and Ethical Challenges," in Doing Cross-Cultural Research (Dordrecht, Netherlands: Springer, 2008), 3-20; Farhana Sultana, "Reflexivity, Positionality and Participatory Ethics: Negotiating Fieldwork Dilemmas in International Research," ACME: An International E-Journal for Critical Geographies 6, no. 3 (2007): 374-85; Zaheer Baber, "Provincial Universalism: The Landscape of Knowledge Production in an Era of Globalization," Current Sociology 51, no. 6 (2003): 615-23. 